УДК 378. 016

DOI 10.11603/me.2414-5998.2020.2.11157

Ya. M. Nakhaieva

ORCID https://orcid.org/0000-0002-6556-0725

ResearcherID Q-6247-2016

I. R. Humenna

ORCID https://orcid.org/0000-0002-2830-7878

ResearcherID Q-5206-2016

I. Horbachevsky Ternopil National Medical University

\title{
THE FORMATION OF TERMINOLOGICAL COMPETENCE OF FUTURE DOCTORS DURING STUDYING HUMANITIES
}

\author{
Я. М. Нахаєва, I. Р. Гуменна \\ Тернопільський національний медичний університет \\ імені І. Я. Горбачевського МОЗ України \\ ФОРМУВАННЯ ТЕРМІНОЛОГІЧНОЇ КОМПЕТЕНТНОСТІ \\ МАЙБУТНІХ ЛІКАРІВ ПІД ЧАС ВИВЧЕННЯ ГУМАНІТАРНИХ \\ ДИСЦИПЛІН
}

\begin{abstract}
The article describes the pedagogical problem of forming the terminological competence of future doctors in higher educational institutions while studying humanities. The emphasis is placed on the fact that reforms in modern education are built not only on the principle of acquiring knowledge and skills, but also on the acquisition of terminological competence of future doctors. The terminological competence of future doctors during the study of humanities is defined as the ability to use professional terms in professional activity, to understand and apply professional expressions in various situations of professional communication with the obligatory use of professional vocabulary, based on the experience gained during university studies. It is proved that the terminological competence acquired by future specialists in higher educational institutions during the study of humanities is the basis for their further professional and scientific activities.
\end{abstract}

Key words: professional competence; terminological competence; future doctors; humanities.

Анотація. У статті охарактеризовано педагогічну проблему формування термінологічної компетентності майбутніх лікарів у закладах вищої медичної освіти під час вивчення гуманітарних дисциплін. Зроблено наголос на тому, що реформи сучасної освіти побудовані не лише за принципом здобуття знань та вмінь, а й набуття термінологічної компетентності майбутніх лікарів. Окреслено термінологічну компетентність майбутніх лікарів під час вивчення гуманітарних дисциплін як сформовану здатність доцільно використовувати фахові терміни під час професійної діяльності, розуміти й застосовувати професійні висловлювання у різноманітних ситуаціях професійного спілкування з обов'язковим використанням фахової лексики, спираючись на досвід, отриманий під час вивчення гуманітарних дисциплін у ЗВО. Доведено, що термінологічна компетентність, якої набувають майбутні лікарі у закладах вищої медичної освіти під час вивчення гуманітарних дисциплін, є базовою у їх подальшій професійній та науковій діяльності.

Ключові слова: професійна компетентність; термінологічна компетентність; майбутні лікарі; гуманітарні дисципліни.

Introduction. Nowadays most of the countries carry out the transition to democratization and informatization of society. Such changes demand constant updates in education as well as making education correspondent to the needs of integration of the world and European educational processes. Such transition stipulates provision of creating educational activity in higher educational institutions on the basis of competences that

\footnotetext{
(c) Ya. M. Nakhaieva, I. R. Humenna
}

involve subject's autonomy in professional activity, enhancement of practical orientation of education, a reflection of specialists' personal features, leading quality of education; focusing educational programs on forming main key competences, their terminological aspect in particular.

In such conditions, only professionally trained doctors can go beyond unplanned and make a correct, reasonable decision and be responsible for it. In this 
context, it is necessary to study the concept of terminological competence and its essence in training future doctors in the study of the humanities.

The aim - to substantiate the concept of the terminological competence of future doctors and distinguish separate aspects of work with its formation during studying humanities.

Theoretical framework. The problem of forming the terminological competence of future doctors has been studied by many modern scientists. Today in Ukraine there are several scientific directions in the research of theoretical and methodical aspects of teaching humanities in higher educational institutions.

Acquisition of basic knowledge on any specialty begins with the combination of general and professional knowledge, that is, professional speech acquisition branch phraseology and terminology that are components of successful professional activity.

One of the quality criteria of training doctors in higher educational institutions is professional competence as an ability to implement the task or work professionally.

Each professional activity differs with its terminology and concepts. Therefore, we consider that terminological competence formation, which is one of the main components of professional competence, is an important stage in training future doctors. In any professional field terminology is one of the important aspects of scientific researches on organization of human being, forming balanced holistic environment during the long term. In the conditions of postindustrial informational society development and globalization, transformation of traditional paradigms and values, terminology remains one of the most important components of professional education.

Knowledge of terminology is necessary for future doctors first of all while reading and understanding professional texts in higher educational institutions in order to get information in the process of studying, writing research papers, etc. and in future professional activity - for professionally-oriented conversation, discussions with foreign colleagues, etc. Therefore, teachers of humanities should pay attention to the main properties of terminological vocabulary, ways of semantization of its meaning in professional texts.

The efficiency of studying terminology and its active use in oral and written professional language during studying humanities depends on the variety of exercises, gradually aimed at substantial terminology acquisition as well as at enhancement of speaking and listening skills which are needed for the use of this terminology in professional situations. Such principles are the basis for development and formation of the terminological competence of future doctors during studying humanities. Theoretical background of the development and substantiation of the process of terminological competence formation during studying humanities are patterns of studying which are traditionally defined as "objective, stable and considerable links in educational process that provide its efficiency" [7] and reflect the correlation between teachers' and students' activity and content of educational material during studying humanities.

Investigation and analysis of scientific works gave an opportunity to define the concept of terminological competence. In particular, scientist T. Denyshchych defines the concept "terminological competence" as 'human ability to understand and create professional speech in different socially determined situations using professional vocabulary and taking into account linguistic and social rules which are followed by native speakers' [3].

We agree with O. Semenoh who defines professional competence as "already existing quality, a real demonstration of acquired knowledge and relevant skills and abilities of a person as a subject of professional activity, having appropriate competences and ability to use them in professional situations" [6].

Patterns that contribute to the formation of terminological competence of future doctors during studying humanities are as follows: educational nature of professional speech development which facilitates development of appropriate features of character and behaviour; dependence on conditions, professional situation of speaking as it creates motives of communication; selection of language means of professional communication; comparison of oral and written language of students of non-philological specialties; enhancement of professional speech; interdependency of methods and techniques during studying humanities in order to form the terminological competence $[2,5]$.

Terminological analysis of the problem gives an opportunity to claim that knowledge of terminology is formed on the basis of common didactic principles (communicative, scientific, systematic, situational, text relevancy principle, illustrative, principles of interrelation of theory and practice, individual approach to students) and are specified by peculiar principles of training (interdisciplinarity, modularity, creativity, individualization, focus on future professional activity) [1]. 


\section{Materials of International Scientific and Practical Conference \\ "PROFESSIONAL AND COMMUNICATION CULTURE OF THE FUTURE DOCTOR: LINGUISTIC, PEDAGOGICAL AND PHILOSOPHICAL ASPECTS”}

Future doctors have to be terminologically competent in the field of their professional activity. Terminological competence is formed on the basis of inseparable combination of deep professional knowledge with the knowledge of speech regulations, rules and mechanisms of functioning of logically-conceptual as well as lexical sub-systems of terminology system, or in other words - on the synthesis of professional and linguistic erudition including knowledge of terms.

At the initial stage of studying humanities future doctors work with medical terminology of scientific texts with more interest and more efficiently. Senior students who already have subject-conceptual basis, understand professional terms, work with terminology of non-adapted authentic medical tests individually [4].

Professional-terminological competence means the ability to use professional terms, knowledge of expressions and structure of phrases correctly and appropriately, acquired skills to create sentences and own dialogues in professional communication situations, basing on the experience gained during studying humanities in higher medical educational institutions and at the same time motivating themselves by relevance of chosen specialty and high results in professional activity and understanding that the key to success is constant practice and self-development.

As it was mentioned above, the efficiency of learning terms and their effective use in oral and written language depend on appropriately selected exercises. Among large amount of variety of exercises the most

\section{List of literature}

1. Власюк I. Формування професійно-термінологічної компетентності майбутніх економістів / I. Власюк // Педагогіка і психологія професійної освіти. - 2012. № 1. - С. 50-58.

2. Гантімурова Н. І. Професійна підготовка студентівіноземців у медичних університетах України / Н. І. Гантімурова, Н. О. Федчишин, Ю. А. Рудяк // Медична освіта. - 2019. - № 4 (84). - С. 5-9.

3. Денищич Т. А. Формування термінологічної компетентності майбутніх фахівців з політології / Т. А. Денищич // Наукові праці Чорноморського державного університету імені Петра Могили комплексу «КиєвоМогилянська академія». Серія «Педагогіка». - 2012. Т. 209, вип. 197. - С. 137-142. efficient are the following: to define the professional term in Ukrainian, to match terms with definitions, to compile terminological dictionary to the text from the coursebook.

Conclusions and Prospects for Research. The relevance of the studied problem is attributed to the importance of forming terminological competence of future competitive doctors during the study of humanities in modern labour market. In general, this research showed us that fluency in professional terminology is a prerequisite for successful professional communication. Therefore, we single out terminological competence during studying humanities in the structure of professional competence as enhanced general linguistic knowledge and professional speech skills influence competent professional activity.

Thus, the formation of terminological competence of future doctors in the study of humanities involves: acquisition of terminological subsystem in the process of studying professional disciplines, vocational and terminological literacy in oral and written language, ability to conduct conversation, analyze, persuade, prove, that is, to solve communicative problems in situations of professional communication. The terminological competence acquired by future doctors in higher medical educational institutions is basic in their further professional and scientific activities.

Prospects for further research in this field are to study peculiarities of formation of terminological competence of future doctors during studying humanities.

4. Мельничук I. Особливості мовної підготовки іноземних студентів до діалогічної взаємодії у майбутній професійній діяльності лікаря / I. Мельничук // Науковий вісник Чернівецького університету. Педагогіка та психологія. - 2014. - Вип. 715. - С. 71-77.

5. Методика навчання української мови в середніх освітніх закладах / М. І. Пентилюк, С. О. Караман, О. В. Караман, О. М. Горошкіна ; за ред. М. І. Пентилюк. - К. : Ленвіт, 2009. - 400 с.

6. Семеног О. М. Професійна підготовка майбутніх учителів української мови і літератури : монографія / О. М. Семеног. - Суми : ВВП «Мрія-1» ТОВ, 2005. 404 c.

7. Фіцула М. М. Педагогіка вищої школи : навч. посіб. / М. М. Фіцула. - К. : Академвидав, 2006. - 52 с. 


\section{Materials of International Scientific and Practical Conference \\ "PROFESSIONAL AND COMMUNICATION CULTURE OF THE FUTURE DOCTOR: LINGUISTIC, PEDAGOGICAL AND PHILOSOPHICAL ASPECTS”}

\section{References}

1. Vlasiuk, I. (2012). Formuvannia profesiino-terminolohichnoi kompetentnosti maibutnikh ekonomistiv [Formation of professional-terminological authenticity of future economic figures]. Pedahohika i psykholohiia profesiinoi osvity - Pedagogy and Psychology of Vocational Education, 1, 50-58 [in Ukrainian].

2. Hantimurova, N.I., Fedchyshyn, N.O., \& Rudyak, Yu.A. (2019). Profesiina pidhotovka studentiv-inozemtsiv u medychnyh universytetakh Ukrainy [Professional training of foreign students in the medical universities of Ukraine]. Medychna osvita - Medical Education, 4 (84), 5-9 [in Ukrainian].

3. Denyshchych, T.A. (2012). Formuvannia terminolohichnoi kompetentnosti maibutnikh fakhivtsiv z politolohii [Formation of the terminological competence of future specialists of politology]. Naukovi pratsi Chornomorskoho derzhavnoho universytetu imeni Petra Mohyly kompleksu “Kyievo-Mohylianska akademiia”. Seriia "Pedahohika”Scientific works of Petro Mohyla Chornomorsk State University Complex “Kyiv-Mohyla Academy”. Pedagogy Series, 197, 137-142 [in Ukrainian].

E-mail address for correspondence: nahaeva@tdmu.edu.ua
4. Melnychuk, I. (2014). Osoblyvosti movnoi pidhotovky inozemnykh studentiv do dialohichnoi vzaiemodii u maibutnii profesiinii diialnosti likaria [Peculiarities of linguistic training of foreign students in dialogical cooperation in doctor's future professional activity]. Naukovyi visnyk Chernivetskoho universytetu. Pedahohika ta psykholohiiaScientific Journal of Chernivtsi University, Pegagogy and Psychology, 715, 71-77 [in Ukrainian].

5. Pentyliuk, S.O. (2009). Metodyka navchannia ukrainskoi movy v serednikh osvitnikh zakladakh [Methods of teaching Ukrainian language in secondary educational institutions]. Pentyliuk, M.I., Karaman, S.O., Karaman, O.V., Horoshkina, O.M. (Eds.). Kyiv: Lenvit [in Ukrainian].

6. Semenoh, O.M. (2005). Profesiina pidhotovka maibutnikh uchyteliv ukrainskoi movy i literatury: monohrafiia [Professional training of future teachers of Ukrainian language and literature: monograph]. Sumy: VVP “Mriia-1" TOV [in Ukrainian].

7. Fitsula, M.M. (2006). Pedahohika vyshchoi shkoly: navch. posib. [Pedagogy of higher educational institution: Textbook]. Kyiv: Akademvydav [in Ukrainian].

Received 22.04.20

Recommended 24.04.20 